
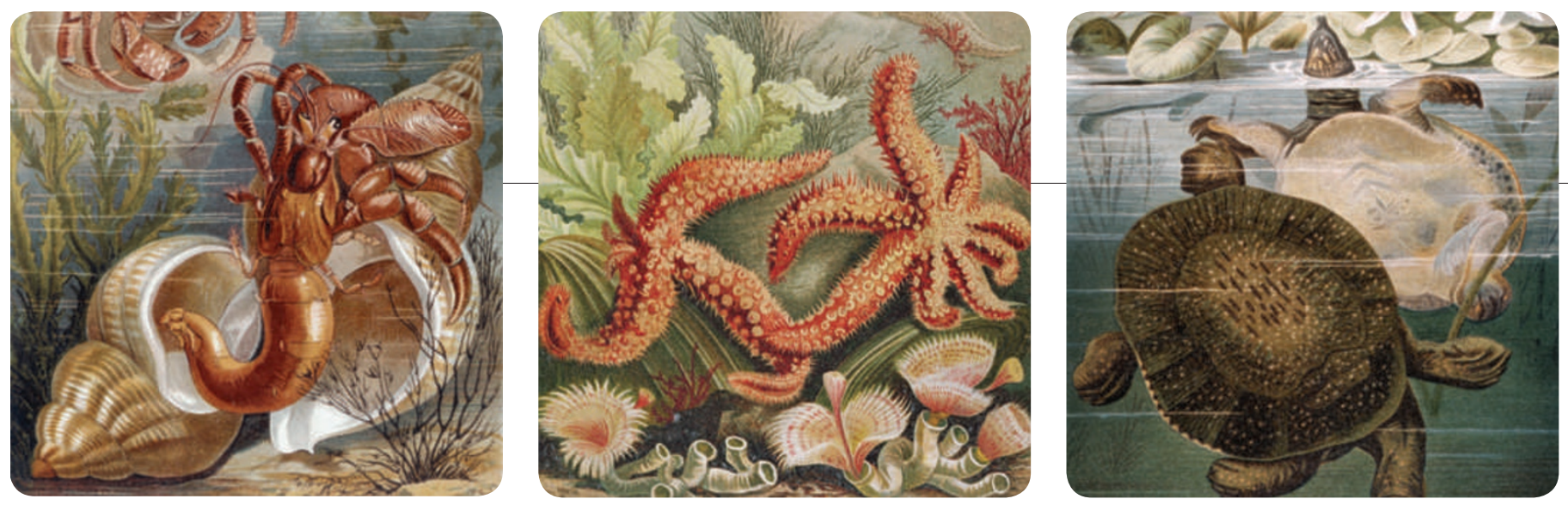

\title{
Poems from Darwin's descendant
}

Amid the many analyses of Darwin's life and work, a more intimate literary portrait emerges from the poetry of his great-great-granddaughter, Ruth Padel. Her series of poems on his life - six of which are reproduced here - evokes the emotion and drama of the naturalist's discoveries.

\section{'The Miser'}

Cross the Welsh Bridge out of town, go up the hill on Frankwell Street and you'll see, above the Severn, brick pillars with the sandy bloom of an ageing dog.

Around the back, Father's surgery and waiting-room.

Outside, the Stable Yard: hay chutes, a piggery and toolshed.

Lower down, a bothy on the river bank

where plates of jagged ice, harvested in winter from the river,

lean one against the other. A dairy where these blocks are dragged

to cool the milk and cream. The Quarry Pool

where he fishes for newts and tadpoles.

Collecting: to assert control

over what's unbearable. To gather and to list.

"Stones, coins, franks, insects, minerals and shells."

Collect yourself: to smother what you feel,

recall to order, summon in one place.

Make a system, like Orpheus, in the face of loss.
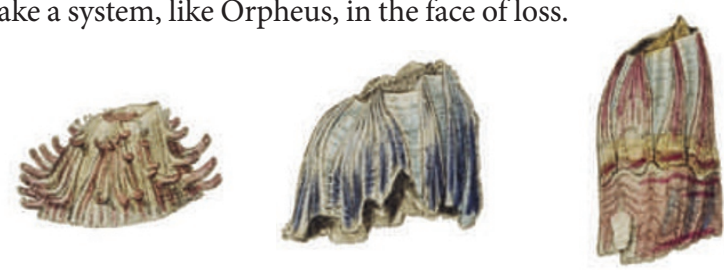

'Plankton'

The deck is dazzle, fish-stink, gauze-covered buckets.

Gelatinous ingots, rainbows of wet flinching amethyst and flubbed, iridescent cream. All this

means he's better; and working on a haul of lumpen light:

polyps, plankton, jellyfish and sea butterflies, the pteropods.

"So low in the scale of nature, so exquisite in their forms!

You wonder at so much beauty - created,

apparently, for such little purpose!" They lower his creel

to blue pores of subtropical ocean. Wave-flicker, white

like a gun-flash over the blown heart of sapphire.

Peacock eyes, beaten and swollen,

tossing on lazuline steel.
'Like Giving to a Blind Man Eyes'

He's standing in Elysium. Palm feathers, a green dream of fountain against blue sky. Banana fronds,

slack rubber rivulets, a canopy of waterproof tearstain over his head. Pods and racemes of tamarind.

Follicle, pinnacle; whorl, bole and thorn.

"I expected a good deal. I had read Humboldt and was afraid of disappointment."

What if he'd stayed at home? "How utterly vain such fear is, none can tell but those who have seen what I have today." A small rock off Africa -

and alone with his enchantment. So much and so unknown.

Like taking a new-born baby in your arms. "Not only the grace of forms and rich new colours: it's the numberless -

\& confusing - associations rushing on the mind that produce the effect." He walks through hot damp air

and tastes it like the breath of earth; like blood.

He is possessed by chlorophyll. By the calls of unknown birds.

He wades into sea and scares an octopus. It puffs black hair

at him, turns red - as hyacinth — and darts for cover.

He sees it watching. He's discovered

something wonderful! He tests it against coloured card and the sailors laugh. They know that girly blush!

He feels a fool - but look, he's touched Volcanic rock for the first time. And Coral on its native stone.

"Often at Edinburgh have I gazed at little pools

of water left by tide. From tiny Corals of our shores

I pictured larger ones. Little did I know how exquisite, still less expect my hope of seeing them to come true.

Never, in my wildest castles of the air, did I imagine this." Lava must once have streamed over the sea-floor here,

baking shells to white hard rock. Then a subterranean force pushed everything up to make an island. His first evidence of Volcano! Vegetation he's never seen, every step a new surprise.

"New insects, fluttering about still newer flowers. It has been for me a glorious day, like giving to a blind man eyes." 
'Algae from the Arctic'

On high trails, the mules leave scarlet dints in snow as if their feet had bled. He scoops up the wet red and rubs it. It isn't claret dust of porphyry, blown

from peaks of the Peuquenes. Nor granite from the blue-roan Portillo ridge. No -

none of this heart-sweeping geology, the Cordillera ashy wind, guanaco flocks

and level-soaring condors

which have bewitched him on this jaunt

to the interior. (He's done so many, now.)

"I felt glad I was by myself. Bright-coloured rocks, profound valleys, heaped ruins and wild broken forms - like watching

a thunderstorm or hearing in full Orchestra

a chorus from The Messiah."

In the microscope, ruby specks glow in ice the mules have squashed. "Like eggs

of small molluscous animals." Or midget ticks full of blood. With Covington, he posts them off to Cambridge - to be identified as algae, from the Arctic.
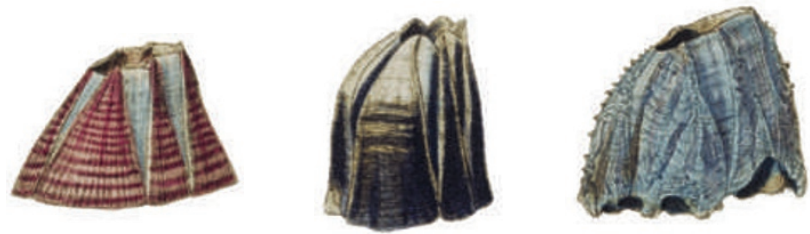

\section{'On Not Thinking About}

\section{Variation in Tortoise-Shell'}

Pure volcano. A mantle of hot bare rock. "Nothing could be less inviting. A broken field of black basaltic lava thrown into most rugged waves and crossed

by fissures." Lava tubes, tuff cones and bright, red-orange crabs. A land iguana! One saffron leathery elbow, powdery as lichen, sticking out

like a man doing press-ups while leering at the sand. And the marine iguana ... "Hideous! An imp of darkness. On Albermarle they seem to grow to a larger size."

Young sea lions nip their tails for fun and fling them in the air like cats with mice. To eat them? No - nothing here, except one hawk, is carnivore; and none afraid of Man.

Look — giant tortoises! "Travelling eagerly, their necks outstretched, to springs. I tried riding on their backs but found it hard to balance! The colony's Vice-Governor

told us he knew which island any shell came from because they differ. I did not for some time pay this enough attention. I never dreamed

that islands sixty miles apart, made of the same stone, of nearly equal height in the same climate, could have different tenants." Fast forward twenty years and you see him write of this scatter-burst of rock in open sea, "We seem brought near that mystery of mysteries, the first appearance of new beings on the earth."

\section{'Painting the Bees'}

The questions buzz at him like birds. They cling

like burrs, delight him like the children, paw like dogs.

They scratch, torment and swarm; they pollinate like wasps. It's got to be vast - proof, evidence, minutiae. Orchids, fertilizing in the greenhouse.

Birdskins from India, the horse-markings of Norway, finch beaks from Galapagos, a parcel of flora from Kew.

How contain all this? Vomit. Panic. Vomit. Nerves in his neck. That wagtail on the lawn -

what muscles make it flick like that; what purpose does it serve? Flatulence. Bad headache. Halfway through.

He steps out through the garden to his thinking path, the Sandwalk. Remembering the trail at Maer around the lake, they have designed a circuit round a copse.

Chasing each question through the undergrowth with his fox terrier, he leaves a pebble at the start of every lap. Into The Dark Side (so the children call it and the little ones are scared). Ivy, tall trees, bushes, lords and lady berries, evergreens. Out past

the sandpit to the Light Side's open view: of sun and cloudshadow over Great Pucklands Meadow.

He loves that children play here. A bugle and boy-laughter that's Frank and Georgy in Crimea. He's drilled them with toy rifles, taught them parts of a gun. Since Beagle, he hasn't used one.

("Shooting is cruel.") They're warming their campfire milk. "Whatever my father did with us," they will say after, "had over it a glamour of delight." His Fool's Experiments! "I shan't be easy till I've tried..." - as if some outside force

were at him with a truncheon. He sets the girls to search for wormcasts. "Damp evenings are best."

Horace finds him snake and lizard eggs, Frank plays bassoon to worms (are they really deaf?) and even flowers

to see how they like vibration. He strings all seven children over long grass and scabious in a chain, to paint and track the bumblebees who pollinate red clover.

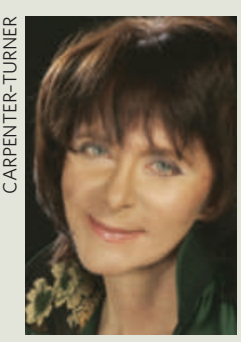

\section{Darwin: A Life in Poems} by Ruth Padel Chatto \& Windus: 2009.160 pp. $£ 12.99$

Prizewinning poet Ruth Padel is Charles Darwin's great-great-granddaughter. Stories told to her by her grandmother, who edited several of Darwin's books, inspired her to compose a series of poems for the bicentenary of the naturalist's birth, a selection of which are reproduced here.

Padel's vivid poetry offers an intimate portrait of Darwin through his life - as a young man marvelling at nature in his own backyard; as an explorer exclaiming on seeing a tropical rainforest for the first time; as a researcher puzzling over his collections in his home office at Down House in Kent, being interrupted by his children playing. Her insight exposes Darwin's thoughts as he pieced together his ideas on evolution, and reflects on how his changing views affected his relationships with his family, the church and society.

To hear Ruth Padel reading her poetry, download the Nature Podcast at http://tinyurl.com/faze2. For more on Darwin, see www.nature.com/darwin. 